ラット肝化学発癌過程に和ける細胞増殖動態と

脞ホルモン環境

村田誠*

要 旨：発癌過程における細胞増殖動態と荤ホルモン環境について，その一端を明らかにする 目的で以下の実験を行った. Solt \& Farber の発癌モデルを用い, 1 週目から 5 週目まで毎週, 細胞増殖動態は autoradiography で解析し, 脞ホルモン環境として insulin と glucagon の門脈 血中と大動脈血中の IRG/IRI および大動脈血中のc-AMP/c-GMPを求めた. Cumulative labelling indexは 1 週目に高く, 以後経時的に低下したが, 明らかな hyperplastic nodule の 出現する 4,5 週目に著明に高くなった. 中央断面の肝細胞数が50個以下の小さい hyperplastic nodule では cumulative labelling index が高く, 中央断面の肝細胞数が200個以上の大きい hyperplastic nodule では cumulative labelling index が比較的低く，増殖能の低下がみられた。 門脈血中の IRG/IRI と cumulative labelling index とはよく相関して変化した.

この事実は, 発癌の promotion 段階で腪ホルモンが重要な役割をになっている可能性を示唆 していると考えられた。

卖引用語： ラット肝化学発癌 細胞増殖動態 autoradiography IRG/IRI c-AMP/c-GMP

\section{はじめに}

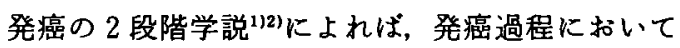
initiationはDNA レベルの変化であり,これには DNA が変化する段階と，それが固定化される段階が あろらと考えられている. そしてDNAの変化の固定 には細胞回転が重要な意味をるつであろらと推測され ている゙!. また, promotionは起始細胞を増殖させる段 階であり，現在までいろいろな promoter が見い出さ れているが，その1つに生体内ホルモン環境があげら れている. 各種のホルモンの中でる腷ホルモンである insulin と glucagon は, in vitroにおいて, 各種の培養 細胞の増殖促進因子の 1 つとして既に知られている.

今回，著者はラット肝化学発癌モデルを用いて，発 癌過程における細胞増殖動態の変化と膵ホルモンであ る insulin と glucagon, および cyclic nucleotide であ るc-AMP とc-GMP の血中濃度の変化について, と くにIRG/IRI とc-AMP/c-GMPについて検討したの で報告する。

* 山口大学医学部第 1 内科（主任：竹本忠良教授） $<$ 受付日59年 5 月 18 日 $>$

\section{材料と方法}

1) 実験モデル (Fig. 1)

$200 \mathrm{~g}$ の Wistar 系雄性ラット100匹を50匹ずつ A, B $2 つ の$ groupに分け, A group は diethylnitrosamine (以下 DEN)，0.02\% 2-acethylaminofluorene（以下 AAF), partial hepatectomy (以下 $\mathrm{PH}$ )を組み合わせ た Solt \& Farber の発癌モデルとし，B groupは最初 にDEN の代りに0.9\% salineを， 3 週後に $\mathrm{PH}$ を施行 したもので、これを control group とした.

2) 方法 (Fig. 1)

A, B 2つの groupkついて 1 週目から 5 週目まで 毎週，10匹ずつ実験に用いた。10匹のうち5匹は屠殺 前17時間前より 8 時間毎に 3 回, $0.5 \times 10^{-6} \mathrm{Ci} / \mathrm{g} の^{3} \mathrm{H}$ thymidine を腹腔内に投与し, 屠殺後, 肝組織を中性ホ ルマリンで固定し, $4 \times 10^{-6} \mathrm{~m}$ の薄切パラフィン切片を 作成し, SAKURA NR-M2 autoradiographic emulsionを用いて dipping methodによる autoradiography 標本を作成した。

Autoradiographyによる観察は，油浸レンズ下（メ 1,000)で核上に 5 個以上の銀粒子をもつ肝細胞を標織 肝細胞とし, 異なる範囲で 1,000 個の肝細胞を 5 回観察 し, 全肝細胞数に対する標識肝細胞数の比を（標識肝 

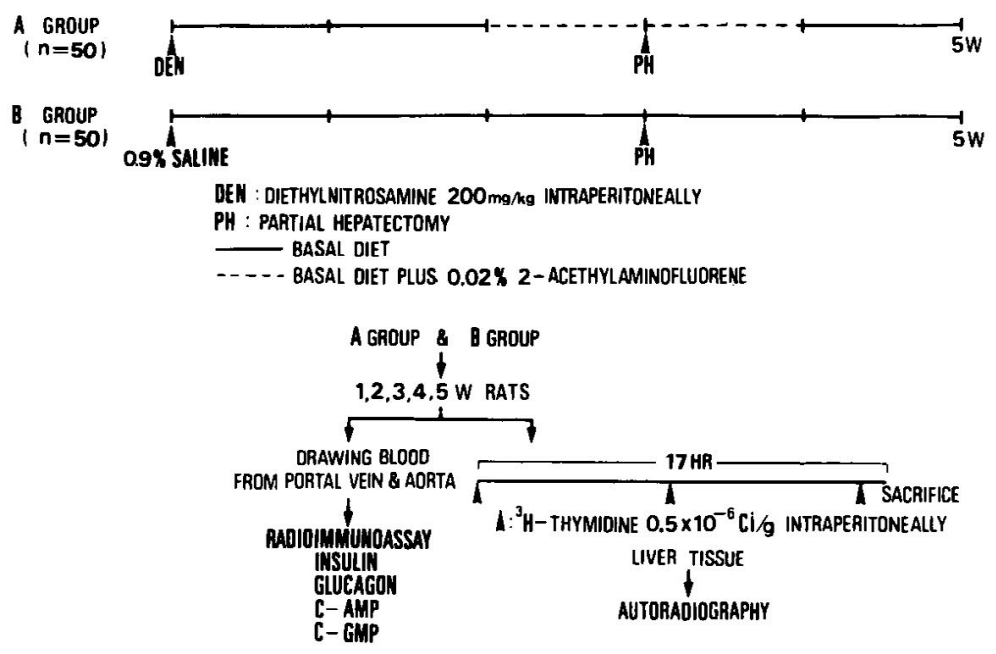

Fig. 1 Experimental design.

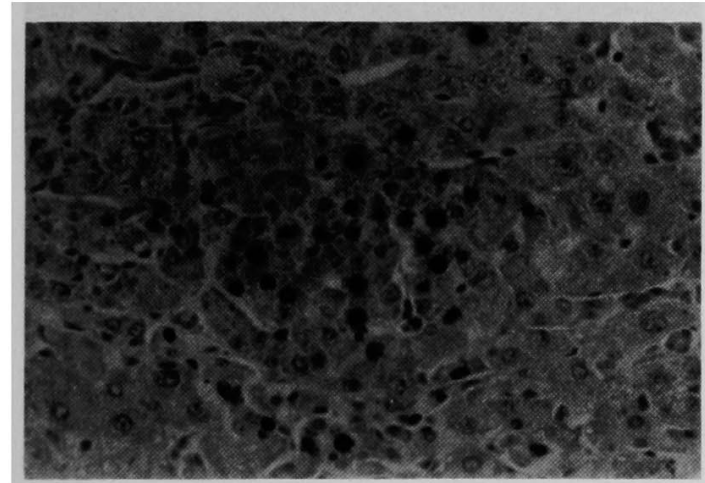

Fig. 2 Small hyperplastic nodule at 4 th week $(x$ 200) Distribution of the labelled cells was dense and diffuse. (diffuse type)

細胞数/全肝細胞数) $\times 100 て ゙$ 表わし, cumulative labelling index (以下 CLI) を求めた. CLIについて, 明ら かな hyperplastic nodule (以下 HPN) の出現のみら れなかった 1，2，3 週目に関しては，全範囲における 倹討に加えて，標識肝細胞の肝小葉内分布を検討する ため, 肝小葉を pericentral area と periportal area の 2つの範囲に分けての検討も加えた。

次に, 明らかな HPN の出現する 4, 5 週目について は，全範囲における検討に加えて，HPN area と surrounding area とに分けてる検討した.

さらに HPN については, HPN の大きさと HPN の内の標識肝細胞の分布状態についても詳細に検討を 加えた。つまり，HPN の大きさは，20連続切片におい， てはほ HPN の中央断面が出ていると思われる標本に

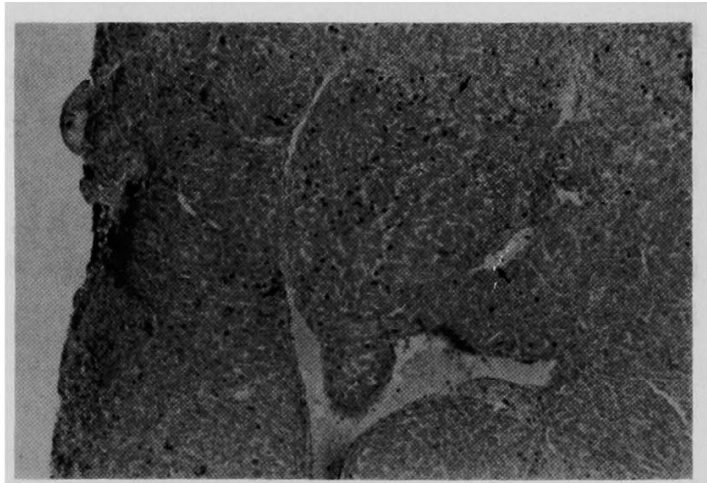

Fig. 3 Large hyperplastic nodule at 5th week ( $x$ 40 , area surrounded by the arrows) Distribution of the labelled cells was multicentric and cumulative labelling index was not so remarkable. (multicentric type)

ついて，その断面の肝細胞数で決定した。また，HPN 内の標識肝細胞の分布状態については, i) ほぼ均一に 標識肝細胞がみられる HPNを diffuse type (Fig. 2), ii） 2 カ所以上に標識肝細胞の集団がみられる HPN を multicentric type (Fig. 3), iii) 偏側にかたよって 多く標識肝細胞がみられる HPNを lateral type, iv) 辺緑に多く標識肝細胞がみられる HPNを border type, v) 中央付近に多〈標識肝細胞がみられる HPN を central type, vi）中央付近执よび辺縁に多く標識 肝細胞がみられる HPNを central \& border type と 分類して，大きさおよび標識肝細胞の分布状態のそれ ぞれの type と CLI との相関について検討した。 
Table 1 Cumulative labelling indices by means of autoradiography ${ }^{(3} \mathrm{H}$ thymidine) through this experiment.

\begin{tabular}{|c|c|c|c|c|c|c|}
\hline & \multicolumn{5}{|c|}{ A GROUP } & \multirow{2}{*}{$\frac{\text { B GROUP }}{\text { TOTAL }}$} \\
\hline & TOTAL & $\begin{array}{l}\text { PERICENTRAL } \\
\text { AREA }\end{array}$ & $\begin{array}{r}\text { PERIPORTAL } \\
\text { AREA }\end{array}$ & HPN" AREA & $\begin{array}{r}\text { SURROUNDING } \\
\text { AREA }\end{array}$ & \\
\hline $1 W$ & $3.7 \pm 1.3$ & $3.4 \pm 1.5$ & $3.9 \pm 1.6$ & - & - & 0 \\
\hline $2 w$ & $0.21 \pm 0.07$ & $0.19 \pm 0.09$ & $0.27 \pm 0.08$ & - & - & 0 \\
\hline $3 W$ & $0.02 \pm 0.007$ & $0.018 \pm 0.009$ & $0.02 \pm 0.007$ & $\longrightarrow$ & $\longrightarrow$ & 0 \\
\hline $4 W$ & $9.4 \pm 2.6$ & - & - & $56.5 \pm 19.9$ & $5.2 \pm 1.6$ & $0.23 \pm 0.07$ \\
\hline $5 W$ & $7.3 \pm 2.4$ & $\ldots$ & - & $41.8 \pm 8.0$ & $3.9 \pm 1.3$ & $0.08 \pm 0.03$ \\
\hline
\end{tabular}

次に, A，B 両 group 残り 5 匹ずつについて，毎週， 屠殺直前に門脈と腹部大動脈よりそれぞれ約 $5 \mathrm{ml}$ ずつ 採血し, insulin と glucagonについては門脈および大 動脈血中濃度を,さらにc-AMP, c-GMPについては 大動脈血中瀑度をそれぞれ radioimmunoassay 法で 測定した。

なお、すべてのラットは屠殺 8 時間前より絶食とし， insulin, glucagon, cyclic nucleotide $の$ 日内変動も考 虑し, 採血は常に午後 6 時に行った.

すべての数値の有意差検定は, $\mathrm{t}$ 検定で行った.

\section{成 績}

1) autoradiography について

CLIの全経過を Table 1に示す。

全経過を通じて,CLIはA groupは B groupよりも 明らかに高かった. A groupにおいて明らかな HPN の出現する前の $1 \sim 3$ 週目では, 1 週目 $3.7 \pm 1.3,2$

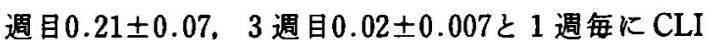
は低下していた。 また，標識肝細胞は肝小葉内にほぼ 均等に分布しており, pericentral area と periportal area とに 2 分して検討したが，両者の比は約 $1 ： 1 て ゙$ あった。

標識肝細胞の特徵については, 1 週目では小型の basophilic cellであることが多く，これらの小型の basophilic cell は数個の細胞集団を形成していること が多かった(Fig. 4). 2，3 週目でも同様の傾向がみら れた.

次に，明らかな HPN が出現する 4,5 週目では，

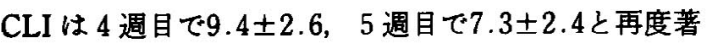
明に高くなり，とくに HPN 内では，4週目，5週目で

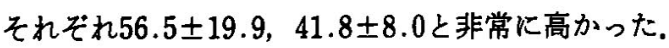

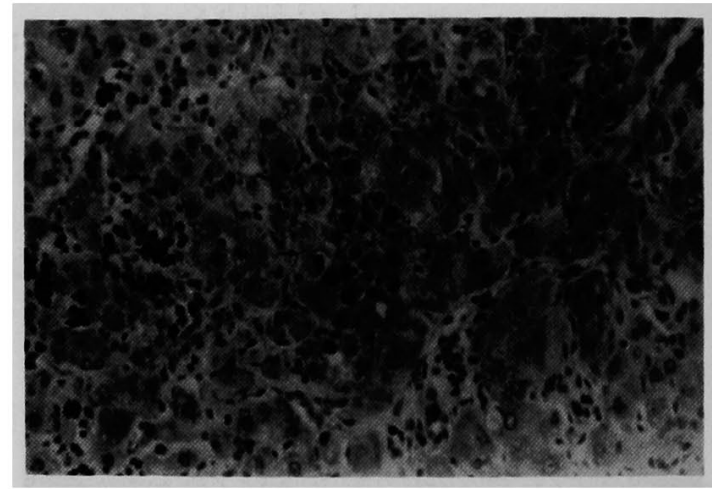

Fig. 4 Distribution of the labelled cells in the liver tissue at lst week $(\times 200)$ Foci of some small basophilic hepatocytes was observed and most of them were labelled. (area surrounded by the arrows)

HPN について詳細に検討すると， 4 週目において， HPN の大きさと CLI との間には Fig. 5に示すよ5に $\mathrm{r}=-0.9467, \mathrm{y}=-0.1671 \times+78.65, \mathrm{p}<0.01$ で有意 に負の相関関係が成り立ち, HPN は小さいものほど CLIが高く，大きいものほどCLIが低かった。

また, HPN 内の標識肝細胞の分布状態の type 別で は，最も多くみられた diffuse type と multicentric type について検討すると，Fig. 6に示すように, diffuse type は multicentric type に比べ $\mathrm{p}<0.05 て ゙$ 有意 に HPN の大きさが小さく，CLI \& $\mathrm{p}<0.01 て ゙$ 有意に 高かった。

5 週目では，HPN の大きさとCLI との間には Fig. 7 示すよらに $\mathrm{r}=-0.5126, \mathrm{y}=-0.0355 \times+47.79$, $\mathrm{p}<0.05$ でやはり有意に負の相関関係が成り立ち, 


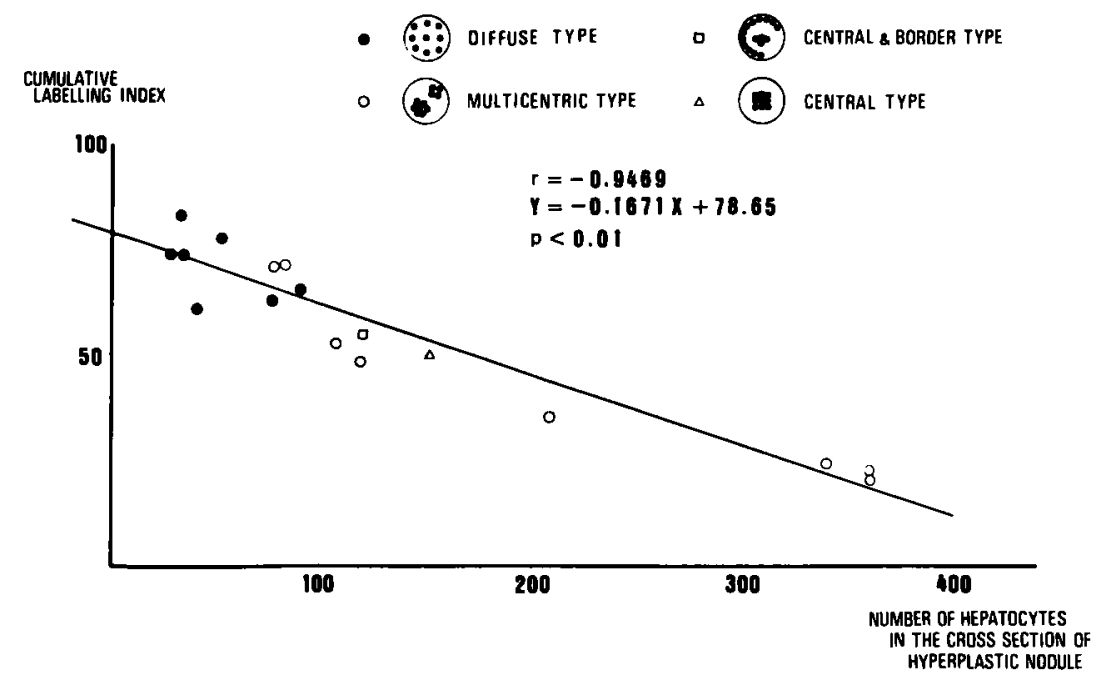

Fig. 5 Correlation between cumulative labelling index and number of hepatocytes in the cross section of hyperplastic nodule at 4 th week. Distribution of the labelled cells in the hyperplastic nodule was classified into 4 types, such as diffuse type $(O)$, multicentric type $(O)$ central type $(\Delta)$, central \& border type ( $\square$ ).

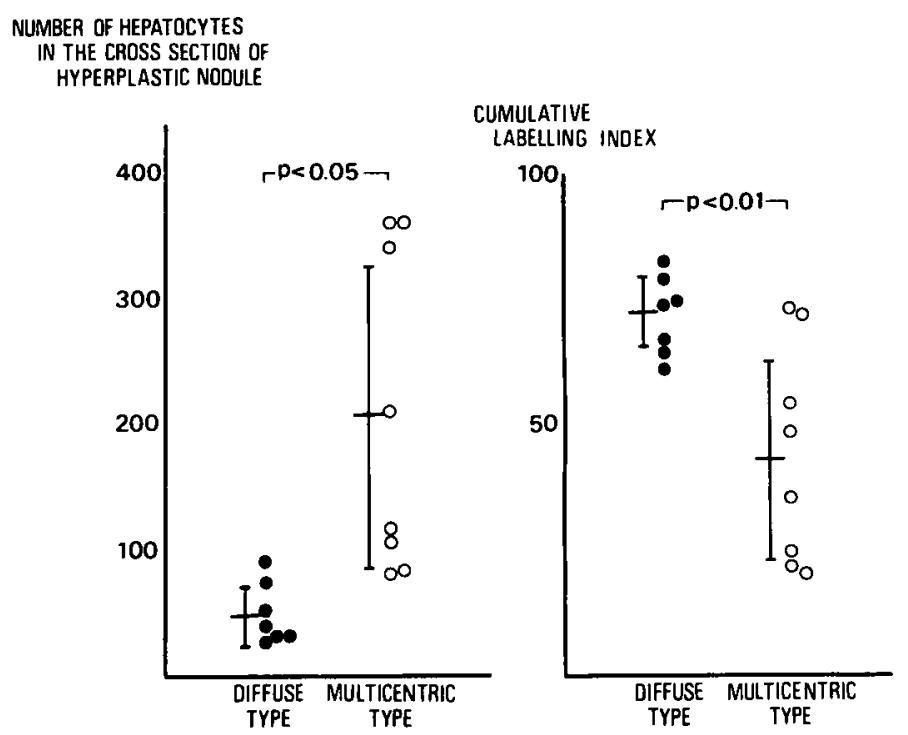

Fig. 6 In the diffuse type and multicentric type, correlation between types of distribution of the labelled cells and cumulative labelling indices or number of hepatocytes in the cross section of hyperplastic nodule at 4 th week.

HPN は小さいものほど CLI が高く，大きいものほど CLIは低かった.ただし、この相関関係は 4 週目に比 べ弱くなっていた。標識肝細胞の分布状態の type 別で は, diffuse type は小さな HPN や大きな HPNなどさ
まざまであり， multicentric type も同様で， 4 週目の ように有意に diffuse typeは小さくて CLIが高く， multicentric type は大きくて CLIが低いといら㑯向 はなかった。 


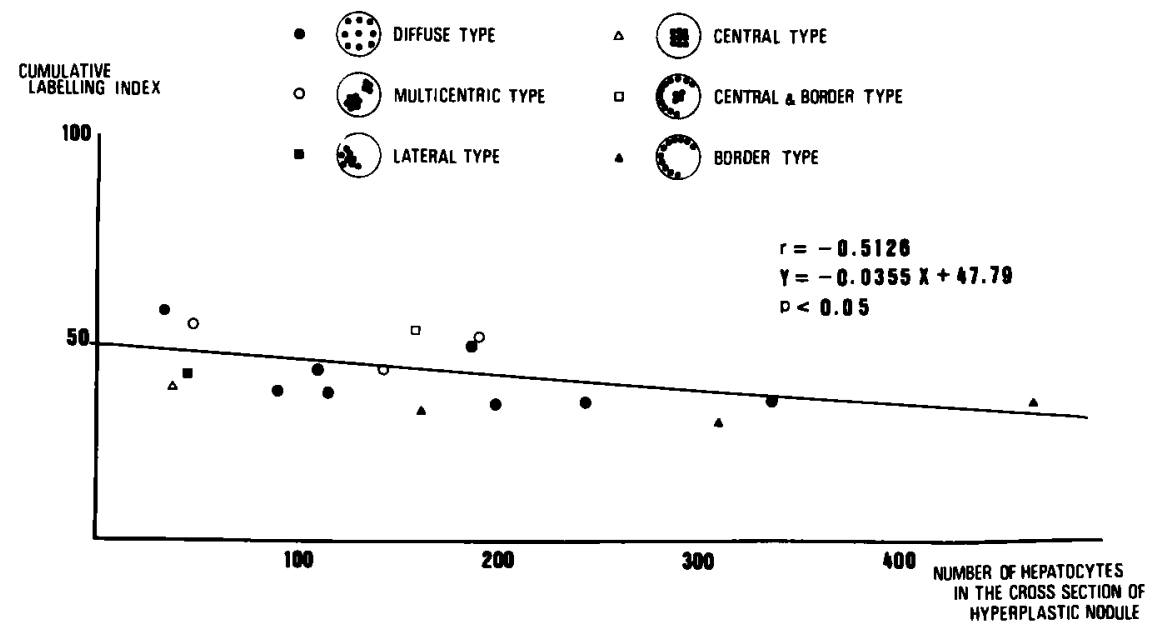

Fig. 7 Correlation between cumulative labelling index and number of hepatocytes in the cross section of hyperplastic nodule at 5th week. Distribution of the labelled cells in the hyperplastic nodule was classified into 6 types, such as diffuse type $(\odot)$, multicentric type $(O)$, lateral type $(\square)$, central type $(\Delta)$, central \& border type ( $\square$ ), and border type ( $\boldsymbol{A}$ ).

次に surrounding areaについてみると, CLIは 4 週

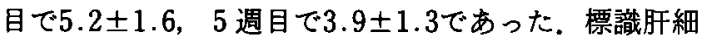
胞はそのほとんどが通常の大きさの肝細胞であった。 control group とした B groupでは， 1 3 週目に おいては，全く標識肝細胞はみられなかった，CLIは

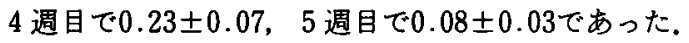

2) insulin, glucagon, cyclic nucleotide $の$ 血中濃 度の变化について

Insulin と glucagon の門脈血中濃度（以下「P」）按 よび大動脈血中濃度（以下「A」）の変化の全程過を
Table 2に示す.

Insulinについて，A groupに拈いて「P」は 1 週目 と 4 週目に高く,「A」は 1 週目と $3 \sim 4$ 週目に高く, それぞれ 2 峰性に変化した。一方，B groupにおいて は,「P」は 1 週目と 4,5 週目に高く, 2 峰性に変化 したが「A」は1週目が最す高值であった。

Glucagon については, A group において「P」,「A」 ともに 1 週目と 4,5 週目に高く，2峰性に变化した が，B groupでは，「P」は 4,5週目に低下㑯向を示 したが，「A」では 2 週目と 5 週目に高く，2峰性に変

Table 2 Insulin and glucagon level in portal and aortic blood through this experiment.

\begin{tabular}{|c|c|c|c|c|c|c|c|c|}
\hline & \multicolumn{4}{|c|}{ INSULIN $\mid \mu \mathrm{U} / \mathrm{ml})$} & \multicolumn{4}{|c|}{ GLUCAGON $\{\mathrm{Dg} / \mathrm{ml} \mid$} \\
\hline & \multicolumn{2}{|c|}{$A$ GROUP } & \multicolumn{2}{|c|}{8 GROUP } & \multicolumn{2}{|c|}{ A GROUP } & \multicolumn{2}{|c|}{ B GROUP } \\
\hline & p & A & $\mathbf{P}$ & A & $\mathbf{p}$ & $A$ & $\mathbf{P}$ & $A$ \\
\hline $1 w$ & $26.5 \pm 16.8$ & $17.3 \pm 12.1$ & $36.2 \pm 19.1$ & $24.4 \pm 8.7$ & $1604 \pm 735$ & $200 \pm 73$ & $709 \pm 365$ & $86 \pm 29$ \\
\hline $2 w$ & $15.2 \pm 5.1$ & $6.4 \pm 1.6$ & $24.1 \pm 11.3$ & $17.0 \pm 5.9$ & $680 \pm 176$ & $160 \pm 32$ & $719 \pm 212$ & $113 \pm 40$ \\
\hline $3 w$ & $19.6 \pm 10.3$ & $11.1 \pm 5.9$ & $26.4 \pm 11.4$ & $17.6 \pm 12.3$ & $711 \pm 233$ & $122 \pm 81$ & $679 \pm 201$ & $93 \pm 29$ \\
\hline $4 w$ & $23.1 \pm 6.5$ & $12.0 \pm 4.7$ & $31.0 \pm 24.5$ & $17.0 \pm 8.53$ & $1075 \pm 396$ & $510 \pm 394$ & $353 \pm 137$ & $96 \pm 14$ \\
\hline $5 W$ & $13.9 \pm 3.9$ & $9.5 \pm 1.47$ & $31.6 \pm 17.5$ & $18.0 \pm 13.6$ & $1816 \pm 670$ & $852 \pm 498$ & $486 \pm 174$ & $162 \pm 82$ \\
\hline
\end{tabular}


化した.

ここでIRG/IRI を求めて検討すると, Table 3, Fig. 8に示すよ5に, A groupにおいては,「P」は 1 週目

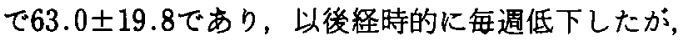
4,5 週目でそれぞれ $48.4 \pm 11.1 ， 118.9 \pm 40.3$ 之再上 昇した。「A」では 2 週目と 4,5 週目に高く，2峰性 に変化した，B group では，「P」，「A」ともに全䅅過 を通じてあまり变化はなかった。 $1 ， 4 ， 5$ 週目に扎い て,A groupは B group に比べ「P」では有意に高く, 「A」では全経過を通じて A group は B group に比べ 有意に高値であった。

次にc-AMP, c-GMP, c-AMP/c-GMP の全䅅過を Table 4, Fig. 9k示す.

c-AMPについて, A groupに拈いては， 2 週目と 5 週目に高く，2 峰性に变化したが，B group では 5 週

Table 3 IRG/IRI level in portal and aortic blood through this experiment.

\begin{tabular}{|c|c|c|c|c|}
\hline & \multicolumn{2}{|c|}{ A GROUP } & \multicolumn{2}{|c|}{ B GROUP } \\
\hline & p & $A$ & $\mathbf{P}$ & A \\
\hline $1 W$ & $63.0 \pm 19.8^{A \prime}$ & $14.0 \pm 5.9^{F / 1}$ & $19.9 \pm 7.0^{49}$ & $3.9 \pm 1.1^{F 1}$ \\
\hline $2 W$ & $43.4 \pm 18.9^{8 !}$ & $24.8 \pm 6.7^{(I)}$ & $27.1 \pm 11.1^{8 / 3}$ & $6.9 \pm 3.0^{G !}$ \\
\hline $3 w$ & $39.1 \pm 14.6^{c)}$ & $8.9 \pm 3.1^{H \prime}$ & $23.8 \pm 9.9^{\mathrm{Cl}}$ & $5.4 \pm 1.9^{H \prime}$ \\
\hline $4 W$ & $48.4 \pm 11.1^{D J}$ & $45.5 \pm 10.3^{11}$ & $13.8 \pm 4.4^{D /}$ & $6.1 \pm 2.3^{11}$ \\
\hline $5 W$ & $118.9 \pm 40.3^{E /}$ & $91.6 \pm 40.0$ & $17.9 \pm 6.1^{E)}$ & $9.8 \pm 3.1^{\prime \prime}$ \\
\hline
\end{tabular}

Values are eXPRESSED AS MEAN $\pm S$. D. "P: IRG/IRI IN PORTAL blOOD $A, O, E, F, G, I, J: D<0.005$ $H: D<0.05$ OF 5 RATS *A: IRG/IRI IN AORTIC BIODD $B, C:$ N.S

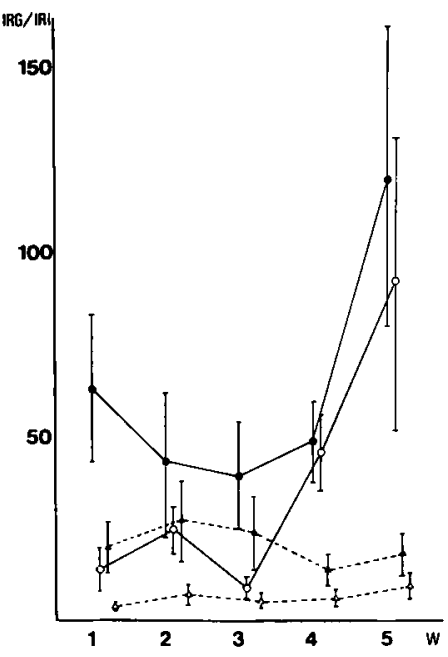

Fig. 8 Changes of IRG/IRI in A and B group. IRG/IRI in portal blood in B group,

$\Delta$ IRG/IRI in aortic blood in B group, IRG/IRI in portal blood in A group, $\triangle \cdots \cdots \cdot \Delta$ IRG/IRI in aortic blood in B group.

目に低下した。. c-GMPについては，A groupはB groupに比べ全経過を通じて低值であった，c-AMP/ c-GMPの関係でみてみると，2 週目と4，5 週目に高 く, 2 峰性に变化した.

以上ををとめると，A groupにおいて「P」のIRG/ IRIはCLI と最もよく相関していた。

\section{考 案}

Solt と Farber" ${ }^{4}$ は, ラット肝化学発癌モデルを作成 し，DEN 投与により出現する basophilic fociはそれ 自体，自律的に增殖する能力はなく， AAF 投与や $\mathrm{PH}$

Table 4 c-AMP, c-GMP, c-AMP/c-GMP level in aortic blood through this experiment.

\begin{tabular}{|c|c|c|c|c|c|c|}
\hline & \multicolumn{2}{|c|}{$c-\mathrm{AMP}(\mathrm{PMOL} / \mathrm{mI})$} & \multicolumn{2}{|c|}{$C-G M P\{\mathrm{pMOL} / \mathrm{ml}\})$} & \multicolumn{2}{|c|}{ C-AMP/C-GMP } \\
\hline & A GROUP & B GROUP & A GROUP & 8 GROUP & A GROUP & B GROUP \\
\hline $1 \mathrm{w}$ & $161 \pm 76$ & $230 \pm 107$ & $21 \pm 7.8$ & $85 \pm 21.1$ & $7.9 \pm 3.4^{A)}$ & $2.8 \pm 0.9^{A)}$ \\
\hline $2 w$ & $230 \pm 40$ & $240 \pm 88$ & $26 \pm 6.3$ & $90 \pm 31.4$ & $8.9 \pm 4.6^{8)}$ & $2.9 \pm 1.1^{\mathrm{B})}$ \\
\hline $3 w$ & $199 \pm 41$ & $230 \pm 100$ & $33 \pm 11.5$ & $77 \pm 30.2$ & $6.4 \pm 1.9^{c)}$ & $3.1 \pm 1.4^{c)}$ \\
\hline $4 w$ & $190 \pm 22$ & $200 \pm 20$ & $16 \pm 6.3$ & $60 \pm 13.0$ & $10.9 \pm 3.1^{0)}$ & $3.5 \pm 0.9^{01}$ \\
\hline $5 w$ & $240 \pm 106$ & $178 \pm 63$ & $22 \pm 8.3$ & $38 \pm 13.9$ & $11.1 \pm 4.0^{E \prime}$ & $4.6 \pm 1.7^{E)}$ \\
\hline
\end{tabular}


$62: 62$

肝

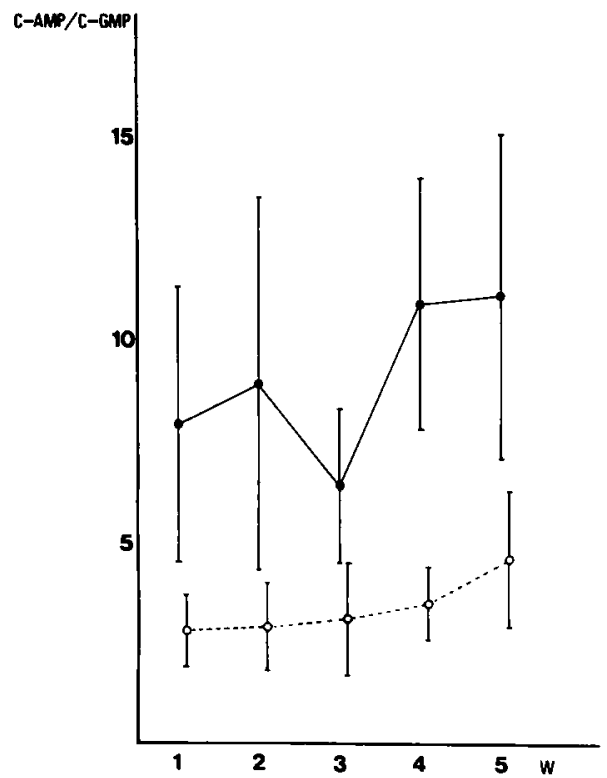

Fig. 9 Changes of $c-A M P / c-G M P$ in $A$ and $B$ group. $\mathrm{c}$-AMP/c-GMP in A group, $O$ -...-O c-AMP/c-GMP in $B$ group.

などの操作により増殖能をもつと述べている，さらに Farber ${ }^{5}$ は promotion について, selection という言葉 を用いて, 起始細胞を選択的に増殖させ, その一部に おいて癌化の諸段階が進行していくことを説明してい る.このことからす発癌過程において, その細胞増殖 動態を解析し，その調節因子を見い出すことは非常に 重要な課題であろらと考えられる。

肝発癌は，ホルモンと深い関係にあり，男性ホルモ ソ6.7)や女性ホルモンター10)が発癌促進の上で重要な役割 をになっているとする報告が多い。また，in vitroにお いても，脺ホルモンである insulinがラット肝癌細胞 にとって増殖促進因子であるといら報告"11もある。

今回, 著者はSolt \& Farberのモデルを用いて細胞 増殖動態と䐙ホルモン環境について検討した。細胞増 殖動態については，Rabes ら ${ }^{12}$ は DEN の連日経口投 与によりラットに作成したさまざまな enzyme deficient area について, labelling index \& cycle time 求めて詳細に検討しているが，これによれば, enzyme deficient area は大きくなる任ど labelling index が高 くなり, cycle time が短かくなっている. DEN の連日 経口投与は明らかに foci の增殖を経時的に促進して いる。著者は DEN 1 回 $200 \mathrm{mg} / \mathrm{kg}$ の腹腔内投与モデ ルを用いており，最初にCLIは上昇したが，以後経時
的に低下していた．DENで誘発された foci はDEN を連続投与しない限り, 細胞增殖動態の面からみれば, 増殖能は低下していくと考学られる. 以後, AAF と PH でdriveをかけることにより，HPN の出現をみと め, 中央断面の肝細胞数が50個以下の小さい HPN は 活発に DNA 合成をし，CLI が高く，中央断面の肝細胞 数が200個以上の大きい HPN では CLIが低くなって いたことは，HPN の成長につれて増殖能が低下し， cycle time の延長あるいは停止する肝細胞が増加する ことを推測させている. AAFを投与していない 5 週 目では, 全範囲の CLI, HPN の CLI は 4 週目と比べて 低下しており，小さな，CLI の非常に高いHPN はみと め難かった。この事実は，PH の全範囲にわたる driv. ing force とAAF の正常肝細胞に対する増殖抑制作 用をよく反映していると考えられる．経時的に増殖能 が低下し, cycle time の延長や停止する肝細胞が增加

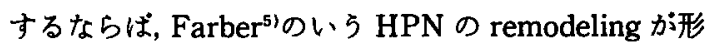
成されていくのかもしれない。この点に関しては，今 後より詳細に検討していきたい。

次に CLIの変化と門脈血中の「P」の変化がよく相 関したことについて述べる，一般に，肝疾患には耐糖 能異常が合併することが多く，菊地ら ${ }^{13.14)}$ の報告によ れば，肝疾患の病態の進展とともに insulin glucagon の相互関俰は insulin優位から次第に glucagon 優位へと移行することが示されている.

In vitrok怙いて insulin $と$ glucagon が広く各種培 養細胞にとって増殖促進因子であることを考えあわ せ，肝をとりまく苹ホルモン環境として門脈血中の IRG/IRI とCLI とがよく相関して变化したことは, 訮 疾患の病態の進展は細胞増殖動態が活発化することで むあり, IRG/IRI という両ホルモンのバランスが細胞 増殖動態に深く関与していると考えられた。

Cyclic nucleotide については，ホルモン作用の sec. ond messenger であるとともに，細胞增殖動態との関 係の有無もかなり論しらられている(15 18). Siefert ら よれば, in vitroにおいて fibroblastic cell は DNA 合 成前に medium 中の c-GMP が增加し，DNA 合成と ともにc-AMPが上昇し，c-GMPは低下することを示 し, c-GMP が細胞增殖の trigger になっている可能性 を示している. In vivoにおける著者の検討では，CLI とc-AMP/c-GMP とはかなり相関して変化してお り，細胞増殖動態と cyclic nucleotide はかなり深く関 保していることがうかがわれた。

以上, ラット肝化学発癌過程において, CLI と聞脈 
血中の IRG/IRI, 大動脈血中の c-AMP/c-GMPがよ く相関して変化したことは，細胞増殖という promotion過程において，苹ホルモン環境やcyclic nucleotideが重要な役割をになっている可能性が推察さ れた.

このことは, ヒト肝細胞癌の発癌と膵ホルモン環境 を考える上で大変重要な証拠になると考えている。

\section{結語}

1. Solt \& Farberのラット肝化学発癌モデルに拉 いて，細胞増殖動態は 1 週目で活発化していたが，以 後経時的に低下した。しかし明らかな HPN の出現す る 4,5 週目で再度急激に活発化した。

2. 4 週目において中央断面の肝細胞数が50個以下 の小さいHPN はCLIが高く， diffuse type がほとん ぞであった。一方，中央断面の肝細胞数が200個以上の 大きいHPN はCLIが低く， multicentric type が多 かった， 5 週目でも小さいHPN はCLI が高く，大き いHPN はCLI が低かったが,この傾向は 4 週目に比 べ弱まっていた。

3.HPN の大きさとCLI との間に有意に負の相関 関係が成立したことは，HPN は成長とともに細胞増 殖能が低下し, cycle timeの延長や停止する肝細胞が 増加することを推察させた。

4. 門脈血中の IRG/IRI とCLI とがよく相関して 変化し, 発癌過程において細胞増殖動態に苹ホルモン 環境が深く関与していることが示唆された。

稿を終えるにあたり，御指導御校閱を賜りました竹本忠 良教授に深甚なる謝意を表します。すた，終始御指導，御鞭 撻を頂きました沖田極講師，御協力下さった研究室各位に 深謝致します.本研究の要旨は, 第43回日本癌学会総会にお いて発表した。

\section{文献}

1) Berenblum I: The mechanism of carcinogenesis. A study of the significance of cocarcinogenic action and related phenomena. Cancer Res 1 : 807-814, 1941

2) Berenblum I: A speculative review: The probable nature of promoting action and its significance in the understanding of the mechanism of carcinogenesis. Cancer Res 14: 471 $-477,1954$

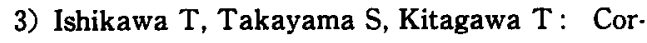
relation between time of partial hepatectomy after a single treatment with diethyl- nitrosamine and induction of adenosine triphosphatase deficient islands in rat liver. Cancer Res $40: 4261-4264,1980$

4) Solt D, Farber E: New principle for the analysis of chemical carcinogenesis. Nature $263: 701$ $-703,1976$

5) Farber E: Chemical carcinogenesis. Am J Pathol 106 : 271-296, 1982

6) Mochizuki Y, Sawada N, Fukukawa K : Effect of bolandiol dipropionate (anabiol), an anabolic hormone, on diethylnitrosamine-induced hepatocarcinogenesis in rat. Gann $72: 969$ $-973,1981$

7) Ishak KG: Hepatic neoplasms associated with contraceptive and anabolic steroids. Recent Result Cancer Research 66: 73-128, 1979 (155 ref.)

8) Taper HS: The effect of estradiol-17-phenylpropionate and estradiol benzoate on $n$ nitrosomorpholin-induced liver carcinogenesis in ovariectomized female rats. Cancer $42: 462$ $-467,1978$

9) Yager JD Jr., Yager R: Oral contraceptive steroids promoter of hepatocarcinogensis in female Sprague-Dawley rats. Cancer Res 40 : $3680-3688,1980$

10) Cameron $R$, Imaida $K$, Ito $N$ : Promotive effects of ethinyl esradiol in hepatocarcinogenesis initiated by diethylnitrosamine in male rats. Gann $72: 339-340,1981$

11) Koontz JW, Iwahashi $M$ : Insulin as a potent, specific growth factor in a rat hepatoma cell line. Sience 211 : 947-949, 1981

12) Rabes HM, Szymkowiak R: Cell kinetics of hepatocytes during the preneoplastic period of diethylnitrosamine-induced liver carcinogenesis. Cancer Res 39 : 1298-1304, 1979

13）菊地 晃, 鬼原 彰：䀒疾患における糖代謝異常 と血中インスリンおよびグルカコンンの相互関係に 関する研究. 第 1 編. ブドウ糖負荷に対する血中イ ンスリンならびにグルカコンン応の病態別変動に ついて。 日消会誌 $75: 1744-1755,1978$

14）菊地 晃, 鬼原 彰: 肝疾患における糖代謝異常 と血中インスリンおよびクルカゴンの相互関係に 関する研究. 第 2 編. ブドウ糖およびアルギニン負 荷に対する血中インスリンならびにグルカコンと 
応の耐糖能別変動について, 日消会誌 $76: 212$ $-222,1979$

15) Tomita $Y$, Nakamura $T$, Ichihara A : Control of DNA synthesis and ornithine decarboxylase activity by hormones and amino acids in primary cultures of adult rat hepatocytes. Exp Cell Res 135: 363-371, 1981

16) Boynton $\mathrm{AL}$, Whitfield JF, Isaacs RJ, et al : An examination of the roles of cyclic nucleotides in the initiation of cell proliferation. Life Sience 22 : 703-710, 1978

17) Richman AR, Weiss JP, Roberts $S B$, et al :
The effect of serum and multiplication stimulating activity on L6 myoblast growth: the lack of correlation with cyclic nucleotide changes. Life Sience 22 : 703-710, 1978

18) Linton HW, Glinos AD : Cyclic nucleotide and growth regulation in suspension cultures of mammalian cells. Am J Phy 103: C131-138, 1980

19) Siefert WE, Rudland PS: Possible involvement of cyclic GMP in growth control of cultur. ed mouse cells. Nature $248: 138-140,1974$

\title{
Experimental study on cell proliferation kinetics and environment of pancreatic hormone in the process of chemical hepatocarcinogenesis in rat
}

\author{
Makoto MURATA*
}

To clarify a correlation between cell proliferation kinetics and environment of pancreatic hormone, this author investigated the cell proliferation kinetics of hepatocytes by means of autoradiography ( ${ }^{3} \mathrm{H}$-thymidine), IRG/IRI in portal and aortic blood and c-AMP/c-GMP in aortic blood in every week until 5th week, using Solt and Farber model.

Cumulative lebelling index was higher at 1st week, but became lower as time passed. At 4th and 5th week, when hyperplastic nedules were seen, the labelled cells were frequently observed, particularly in the small hyperplastic nodules. On the other hand, this indices were lower in the large nodules and this fact might indicate cell proliferation became weak and number of hepatocyte which cell cycle became longer or out of phase increased as hyperplastic nodule grew. The ratio of IRG/IRI in portal blood changed in the same manner as the cumulative labelling index until 5th week.

These observations suggest that pancreatic hormone may play an important role in the process of promotion in hepatocarcinogenesis in rat.

\footnotetext{
* The First Department of Internal Medicine, Yamaguchi University, School of Medicine (Yamaguchi)
} 